\title{
CHEMICAL BEHAVIOUR OF TRACE POLLUTANTS DURING ROOF AND ROAD RUNOFF
}

\author{
Reimer HERRMANN, Joachim DAUB, Jürgen \\ FORSTER and Thomas STRIEBEL \\ Chair of Hydrology, University of Bayreuth, \\ 95440 Bayreuth, Germany
}

\section{ABSTRACT}

The fates of ionic and nonionic organic compounds and trace metals during roof and road runoff are sensitive to their distribution between sorption onto roof and road material and suspended sediments on the one hand and dissolution on the other hand. Using field data of runoff, suspended sediment concentration and the chemical state of various trace pollutants, we try to explain the factors governing the chemodynamics and the transport behaviour during roof and road runoff.

\section{INTRODUCTION}

We will transfer the reasoning of $\mathrm{CHIOU}$ et al. (1985) about the sorption of nonionic organic compounds onto soil humus and minerals to the understanding of chemodynamic behaviour of nonionic organic pollutants on roofs and roads. We extend this reasoning further to hydrophobic ionizable organic chemicals (e.g. phenols) and mixtures of water and organic solvents (e.g. DOC) (SAWHNEY 1989, RAO et al. 1989). We should expect that wet surfaces of roof and road material and suspended sediments, both coated with organic material, would linearly, and without competition between different solutes, uptake nonionic organic compounds from water by means of solute partitioning into organic matter. However, decreasing with in creasing dipole interaction of water with minerals, nonionic organics will be adsorbed on the minerals' surfaces by entropy driven processes. This process leads to competition between the various adsorbates in a mixture.

Strong vapour phase sorption by dry surfaces of roads, roofs and sediments can be explained by mineral adsorption which holds commanding influence of adsorption onto surfaces.

During wetting of surfaces, part of the previously adsorbed nonionic organic chemicals will desorb, others will partition into the organic material. However, the uptake of organic chemicals by organic coatings on wet roofs, roads and sediments is small in relation to organic solvents. In case of low contents of organic matter on road and roof surfaces, we should expect a change of activity of organic chemicals during wetting and drying cycles, because after wetting of the surface, water will displace the nonionic organic chemical from the mineral surfaces.

As an example of hydrophobic ionizable hydrocarbons SAWHNEY (1989) discusses the sorptive behaviour of phenols. Partition coefficients predicted from water solubility or wateroctanol partitioning are lower than those measured in sedimentwater systems. He explains this discrepancy by sorption processes of phenols by soils and sediments which are related to specific interactions, such as by $\mathrm{H}$-bonds (s. fig. 1 ), rather than by general hydrophobic mechanisms. Furthermore, phenolic compounds with a pka lower than the $\mathrm{pH}$ of roof or road runoff will dissociate, and the resulting phenolate has a much greater solubility than the protonated form.

Dissolved organic compounds act as cosolvents, thus decreasing sorption of organic chemicals on surfaces and decreasing the sorption coefficient. The result is a greater mobility of the organic chemical as a dissolved species within the runoff.

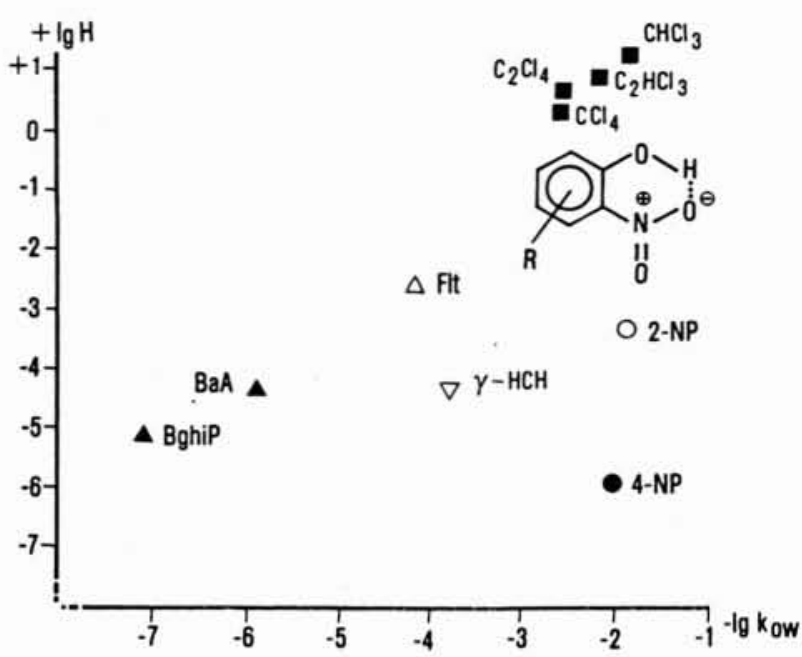

Figure 1: Plot of Henry's law constant $\mathrm{H}$ against octanol-water partition coefficient $k_{\text {ow }}(\triangle \equiv M(P A H)<202, \boldsymbol{\Delta} \equiv M(P A H)$ $>202 \mathrm{~g} \mathrm{~mol}-1, \mathrm{O} \equiv$ (ortho-)nitrophenol with intramolecular $\mathrm{H}$ bonds, $\bullet$ (para-)nitrophenol with intermolecular $\mathrm{H}$-bonds).

LISS and SLATER (1974) describe the use of a two layer model to estimate the flux of various gases across the air-water interface. The total resistance on a liquid phase basis $\left(\mathrm{K}_{i}^{-1}\right)$ depends on the exchange constants $k_{f}$ and $k_{g}$ of the individual phases and the dimensionless Henry's law constant of the gas $(\mathrm{H})$ :

$K_{i}^{-1}=K_{i}^{-1}+\left(H k_{g}\right)^{-1}$

Because of high values of $\mathrm{H}$ of all the volatile organic hydrocarbons we investigated, the liquid phase resistance controlls the exchange $\left(\mathrm{k}_{\mathrm{i}}^{-1}>\mathrm{H} \mathrm{k}_{\mathrm{g}}^{-1}\right)$.

We plotted the distribution coefficient of the air-water system (Ig HENRY's law coefficient) against the octanol-water partition coefficient $\left(\mathrm{lg} \mathrm{k}_{\mathrm{ow}}\right)$ in fig. 1 for a few trace organics : the volatility increases upward and the sorption increases to the left, thus the capability of escaping the aqueous phase decreases towards the lower right.

We will select examples for the dominant chemodynamic and transport processes which affect the behaviour of organic chemicals during roof and road washoff. However, since at any time no single process acts alone, real world behaviour of organic chemicals cannot definitely be attributed to the single contributing chemical processes.

The explanation of the chemodynamics of trace metals during roof and road runoff is severely limited as we do not know sufficiently of most of the influencing factors, e.g. the kinetics of dissolution and precipitation, the thermodynamic data and ligand concentrations, in order to estimate inorganic and organic metal complexes, and their saturation, and finally the data for computing sorption processes onto roof and road surfaces and onto suspended sediments. Especially the kinetics of partitioning of trace metals into or out of suspended sediments or roof and road material is not well known.

The sorption capacity of suspended sediments and roof and road surfaces primarily depends on the coating of the surfaces by amorphic oxides of $\mathrm{Fe}$ and $\mathrm{Mn}$ and by reactive organic carbon. Further, clay minerals and amorphic $\mathrm{Al}$ and $\mathrm{Si}$ oxides act as sorbents for trace metals or they form substrates which can be coated by $\mathrm{Fe}$ and $\mathrm{Mn}$ amorphic oxides or reactive organic carbon.

For a comprehensive treatise on the behaviour of trace metals in the hydrocycle, we refer to the monograph of SALOMONS and FÖSTNER (1984).

Analogous to soils, we can expect that surfaces of suspended 
sediments and of roofs and roads present great numbers of surface coordination sites. Normally we observe a significant hysteresis between sorbing and desorbing trace metals resulting from the metals partly entering the solid material or from diffusing into micro-pores or a larger endothermic energy need. Thus, desorption needs more time to equilibrate than sorption does.

Besides the composition of the surfaces, the composition of the solute, too, influences the sorption behaviour of trace metals during roof and road runoff. The $\mathrm{pH}$ strongly influences the sorption of trace metals by hydrolysis or protonation of the ions and changes the charge of the surfaces.

Besides some exceptions, the complexation of trace metals by organic and inorganic ligands decreases the sorption onto surfaces and increases the mobility of the trace metals.

We are not able to predict the results of competitive behaviour of a trace metal and constituents of the solute, which potentially can adsorb at the same surface sites like the trace metal under consideration, since we generally do not know the composition of the solute and of the surfaces. Though the ionic strength affects trace metal sorption to a lesser degree than proton activity, complexation or competition, it influences metal ion activity in solution and the surface charges. Further it influences the formation of aggregates and thus sorption or desorption by increasing or decreasing the active surface area of the solid phase.

\section{STUDY AREA, SAMPLING AND CHEMICAL ANALYSIS}

For this study we selected three road sections [HERRMANN et al. 1992, KERN et al. 1993] in the city of Bayreuth, five roofs within the university campus [FORSTER 1990] and five experimental roofs on top of a flat roof also within the university campus [FORSTER 1991]. We developed automatic sampling systems [FORSTER 1991, STRIEBEL et al. 1993] which allowed to take samples and to measure runoff, electric conductivity and $\mathrm{pH}$ with high temporal resolution. We analyzed the organic micropollutants by means of solid phase and liquid/solid extraction, a cleanup step, GC and HPLC separation and ECD, MS, and fluorescence detection. Depending on their position within the speciation scheme, we measured trace metals by means of atomic absorption spectroscopy (AAS) and anodic stripping voltammetry (ASV) with or without pretreatment (e.g. ion exchange, acid digestion under pressure or UV-radiation).

\section{CHEMODYNAMICS AND TRANSPORT BEHAVIOUR OF TRACE ORGANIC COMPOUNDS}

\subsection{SORPTION PROCESSES}

A plot of normalized freight sums against normalized flow mass (fig. 2) provides evidence that, during road washoff, fluoranthene sorbed by suspended sediments behaves like the suspended sediments themselves, whereas the behaviour of dissolved fluoranthene can be compared with that of DOC.

However, at times with intensive runoff, coarse suspended sediments are eroded, which have a lower ratio of organic coatings to mineral surfaces and thus a lower overall sorption capacity. As a result, the specific adsorption declines (s. fig. 3).

The combination of time series of temporal variations of dissolved and sorbed fluoranthene with that of DOC indicates that the ratio of dissolved to sorbed fluoranthene during road washoff can at times be considerately higher than one would predict from the high $\mathrm{k}_{\text {ow }}$ (s. fig. 1). We explain this behaviour by cosolvation by nonpolar films of mineral oil, dissolved low molecular organic

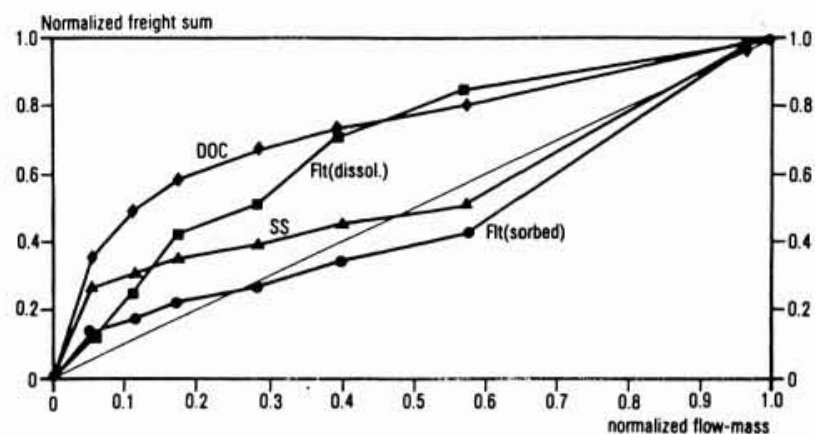

Figure 2: Road-runoff event : plot of normalized freight sums of fluoranthene (FIt), suspended sediments (SS) and DOC against normalized flow-mass (Bayreuth, Königsallee, 14/07/1991).

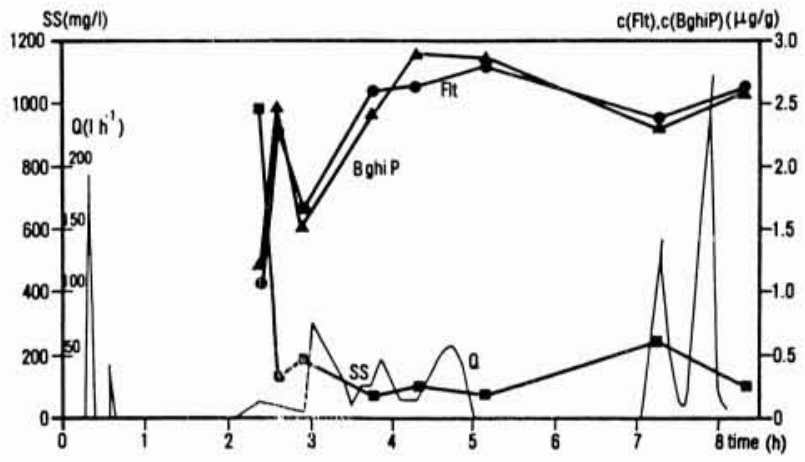

Figure 3: Temporal variation of specific concentrations of sorbed fluoranthene (FIt), benzo(ghi)perylene (BghiP), suspended sediments (SS) and runoff (Q) during road washoff (Bayreuth, Königsallee, 14/07/1991).

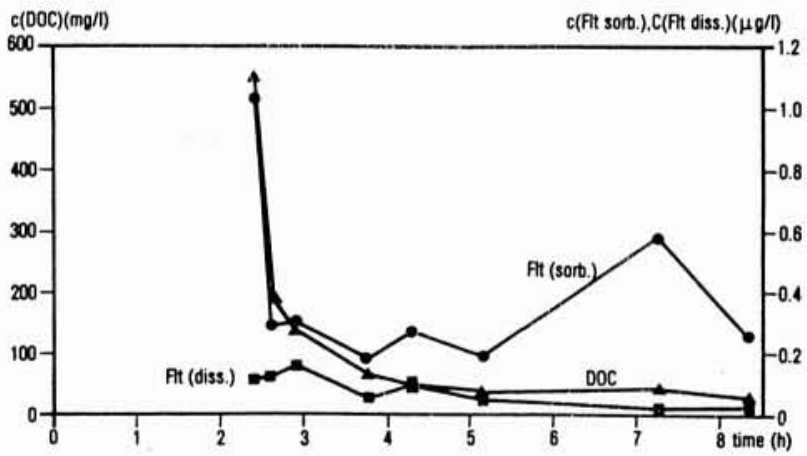

Figure 4: Temporal variation of dissolved (diss.), sorbed (sorb.) fluoranthene (FIt) and DOC during road washoff (Bayreuth, Königsallee, 14/07/1991).

chemicals, nitrophenols or other organic solvents (fig. 4). We observed this behaviour in particular with nonionic organic chemicals with very high sorption coefficient : during an event with $\mathrm{c}(\mathrm{DOC})=2-10 \mathrm{mg} / \mathrm{l}$, the ratio roof dissolved fluoranthene/BghiP was $r=7$, however at an another event with $c(D O C)=27-545 \mathrm{mg} / \mathrm{l}$ the same ratio decreased down to $r=1$.

During dry weather, $\gamma-\mathrm{HCH}$ (Lindane) deposits on roofs and roads in the gaseous phase. During wetting of the surface, this organic compound, which is only weakly adsorbed by minerals $\left(\lg k_{d}<2\right)$ and has a solubility of $s=15 \mu \mathrm{mol} / \mathrm{l}$, will readily 


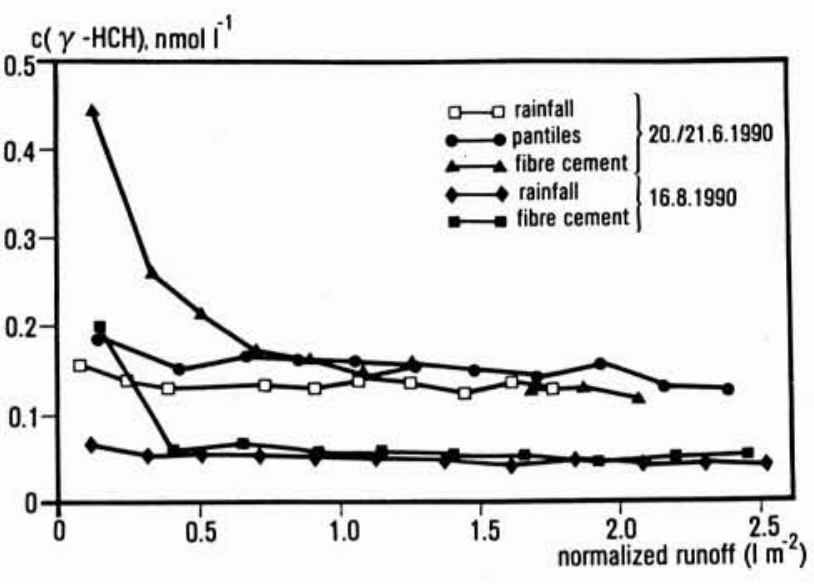

Figure 5 : Concentrations of $\gamma-\mathrm{HCH}$ during roof washoff from pantiles and fibre cement.

desorb, and during the course of a runoff event will adopt concentrations of the feeding rainfall. Thus, at onset of rain, roofs with a higher inner mineral surface, like fibre cement, exhibit a considerable higher concentration of $\gamma-\mathrm{HCH}$ in surface roof washoff than does the rain (s. fig. 5).

Because of their high solubility (s. fig. 1), nitrophenols as an example of hydrophobic ionizable hydrocarbons are easily mobilized during road washoff. Nitrophenols with intermolecular $\mathrm{H}$-bonds or $\mathrm{pk}_{\mathrm{a}}<\mathrm{pH}$ like 4-nitrophenol in our example $\left(\mathrm{pk}_{\mathrm{a}}=7,1\right)$ show a marked first flush effect (s. fig. 6). Contrary, the transport of nitrophenols adsorbed onto suspended sediments is in most cases below the limit of determination and in general negligible. During times of intensive rainfall the concentrations of nitrophenols decrease in road washoff caused by dilution and lower contribution by dissolution. Near the end of a rain event, however, concentrations in washoff are controlled by concentrations in rainfall. Further, during summer events with low runoff, warm road surfaces cause evaporation with the effect of an increase of nitrophenol concentrations. During strong road washoff the more mobile 4-nitrophenol reaches a state of supply limit considerately earlier than the less soluble and mobile 2nitrophenol.

\subsection{TRANSPORT ACROSS THE WATER-AIR INTERFACE}

Caused by high HENRY's law constants and low octanol-water

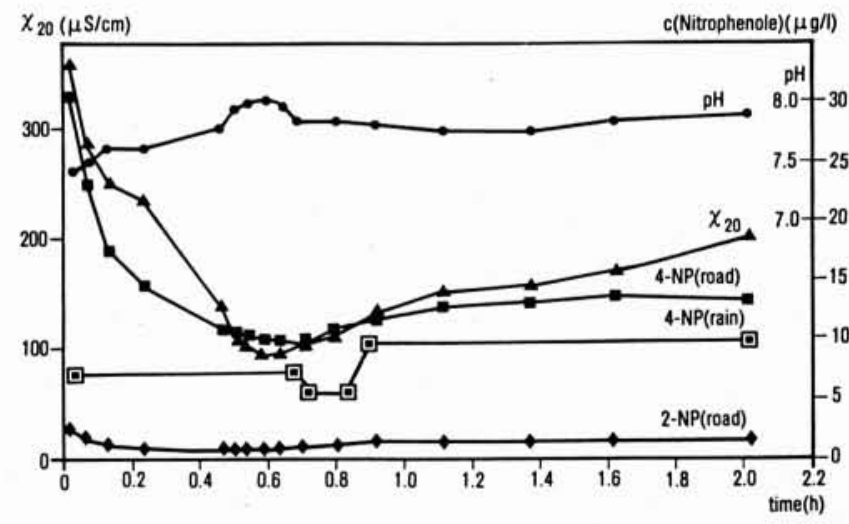

Figure 6: Temporal variations of dissolved 2-nitrophenol (2NP), 4-nitrophenol (4-NP), electric conductivity $\left(\chi_{20}\right)$ and $\mathrm{pH}$ during road washoff. For 4-NP, the concentrations in rain are also plotted (Bayreuth, Albrecht-Dürer-Straße, 08/05/1990). partition coefficients $k_{\text {ow }}$, volatile chlorinated hydrocarbons (s. fig. 1) tend to easily equilibrate with the air, do not significantly deposit in vapour phase on road and roof surfaces, and do not significantly sorb onto mineral or organic surfaces. Thus, the concentrations of this class of nonionic organic hydrocarbons in roof and road washoff are governed by their concentrations in rainfall, and as a result the deviation of their normalized freight sum from the specific flow-mass is very low.

\subsection{PHOTOCHEMICAL REACTIONS}

Comparing the concentrations of benzo(a)anthracene (s. fig. 7) in roof washoff from a tin roof and a concrete tile roof from north and south sides we observe that there is no significant difference which could be interpreted to be caused by photochemical breakdown. The apparent differences which change during the event may be caused by different hydrodynamics and different dry deposition in luff and lee as well as different residual mass left over from previous rainfall. ZARIFIOU et al. (1984) warn that great care must be taken to avoid experimental artifacts when dealing with photochemical reactions.

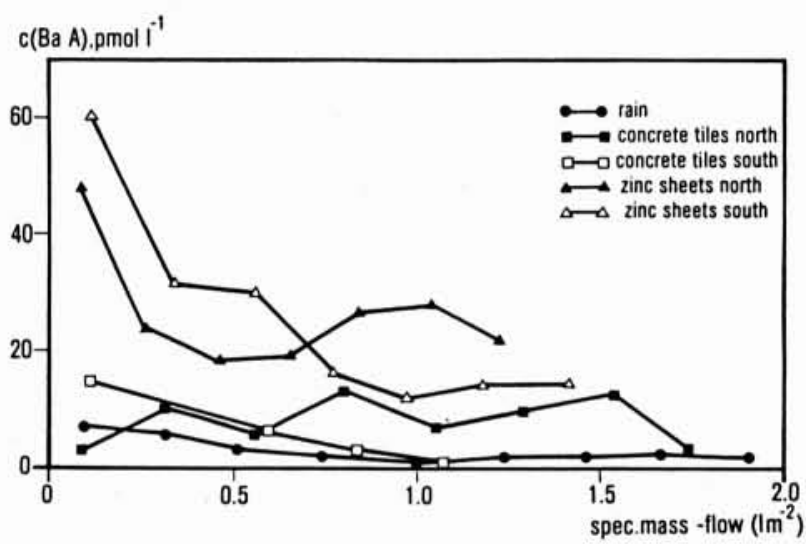

Figure 7: Temporal variation of concentrations of benzo(a)anthracene $(\mathrm{BaA})$ during roof washoff on north and south sides.

\section{CHEMODYNAMICS AND TRANSPORT BEHAVIOUR OF TRACE METALS}

\subsection{SPECIES DISTRIBUTION : CHEMICAL SPECIATION}

Using two examples of chemical speciation, a meltwater and a rain runoff event (s. fig. 8), we want to emphasize that the species distribution, and thus sorption and transport behaviour. may change considerably between and within runoff events. During the meltwater event with high ion concentration $\left(\chi_{20}=\right.$ $36.000 \mu \mathrm{S} / \mathrm{cm}$ ), Cu was transported in equal shares in dissolved and adsorbed phases. The contribution of dissolved $\mathrm{Cu}$ was comparatively high. About a third of the dissolved Cu is ASV. labile bound, and this portion cannot be increased by UVradiation. Equally, the portion of Chelex-labile metals does not increase. Thus, the not labile bound $\mathrm{Cu}$ species either exist as very stable inorganic complexes which do not disintegrate under the influence of a strong ion exchanger or as colloidal $\mathrm{Cu}$ species. The rain runoff resulted from a weak rain event, and thus the concentration of suspended sediments and as a result the transport of $\mathrm{Cu}$ in adsorbed phase was only low. Also, the 
ASV-labile bound Cu was only low, but could be considerably increased by UV-radiation: a clear indication of ASV-stable, organic complexing agents. As the Chelex-labile and the UVASV-labile portions nearly sum up to the concentration of total dissolved $\mathrm{Cu}$, dissolved $\mathrm{Cu}$ is practically completely exchangeable, but not existing in an extremely labile form.

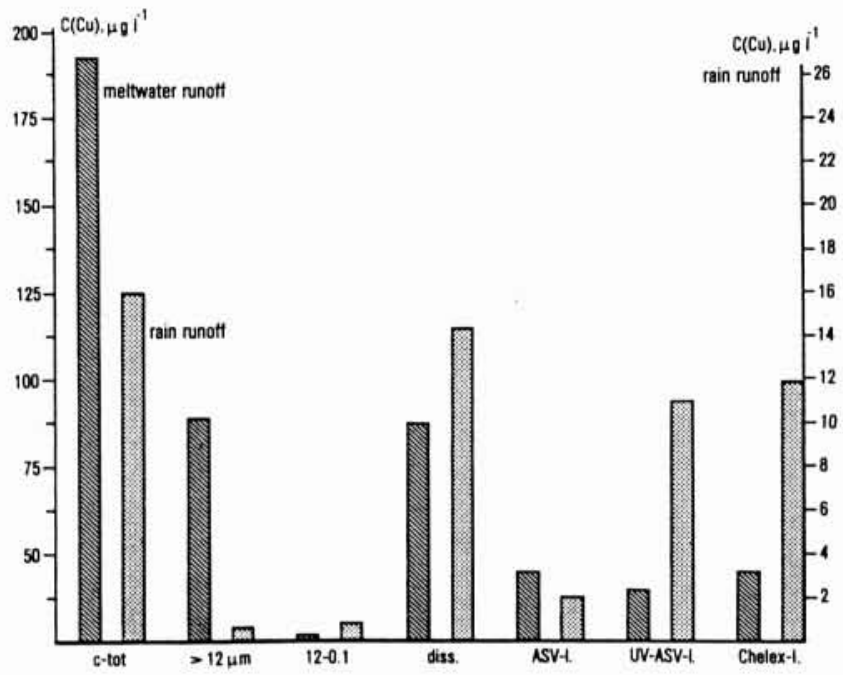

Figure 8: Chemical speciation of $\mathrm{Cu}$ in meltwater and rainwater runoff samples (Meranierring, Bayreuth)

\subsection{METAL SPECIATION BY MEANS OF THERMODYNAMIC EQUILIBRIUM}

Computation (s. fig. 9) reveals that the separation into free dissolved and inorganic metal complexes cannot be related to the general state of contamination of a runoff sample. Rather the separation depends on the availability of the complexing ligands. $\mathrm{Cu}$ tends to complex with chloride and sulfate as well as with hydroxide and carbonate. As a result, we observe at the " high contamination case " a significant complexation by chloride and sulfate caused by the availability of these anions and a low $\mathrm{pH}=6,2$. This low $\mathrm{pH}$ caused a low carbonate and hydroxide complexation and a high concentration of free $\mathrm{Cu}$. On the other hand, low chloride and sulfate concentrations and a high $\mathrm{pH}=7,6$ at the "low contamination case " shift the species distribution to a dominant carbonate and hydroxy-complexation.

The species distribution of $\mathrm{Pb}$ is caused by the same governing factors. However, the distribution is reduced to sulfate and hydroxide complexes, which are related to contamination and $\mathrm{pH}$, resp., and to free dissolved $\mathrm{Pb}$.

In case of $\mathrm{Cd}$, only chloride and sulfate complexes and free $\mathrm{Cd}$ are of importance. Thus, the species distribution is clearly related to the availability of chloride and sulfate caused by contamination.

In most cases concentrations of the three metals are below saturation. Only in the "low contamination case " we computed a weak oversaturation $(\mathrm{SI}=+0,1)$ of free $\mathrm{Cu}$ against $\mathrm{CuO}$. This oversaturation may be a computational or experimental artefact caused by neglect of monovalent $\mathrm{Cu}$ ions, neglect of organic ligands or inclusion of colloidal $\mathrm{Cu}$ which passed the filter. Thus, we cannot refute the hypothesis, that the concentrations of dissolved trace metals are governed by competitive reactions between adsorption equilibria related to adsorption sites and dissolved complexes.

\subsection{INFLUENCE OF DIFFERENT ROOF MATERIALS ON TRANSPORT BEHAVIOUR}

FORSTER (1990) investigated the pollutant load of runoff of five
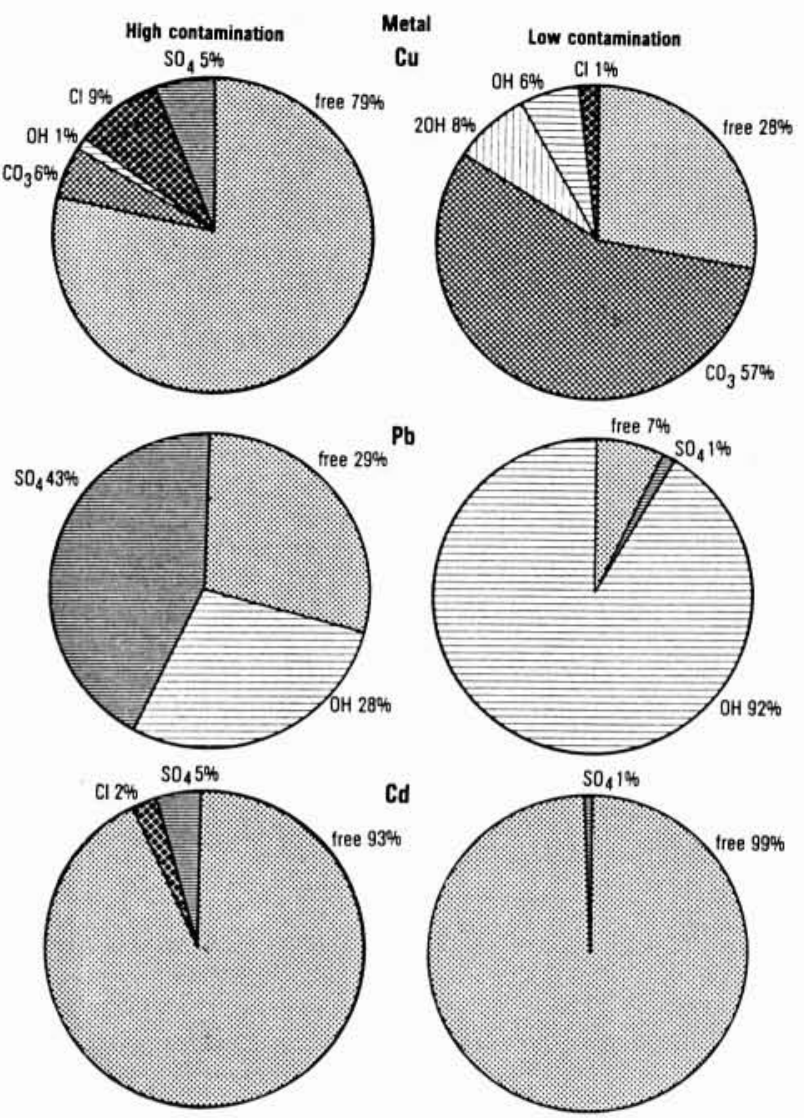

Figure 9: Thermodynamic speciation of $\mathrm{Cu}, \mathrm{Pb}$ and $\mathrm{Cd}$ in a road runoff with low and high contamination (Meranierring, Bayreuth).

roofs with different materials and slopes between $15^{\circ}$ and $30^{\circ}$ and one flat roof. During the runoff event presented (s. fig. 10) the mean concentrations of suspended sediments in runoff related to that of rain c(ss, rain) $=17 \mathrm{mg} / \mathrm{dm}^{3}$ were : tarfeld roof $=258 \%$, pantile roof $=211 \%$, fibre cement $=281 \%$, zinc sheet roof $=399 \%$ and flat gravel roof $=26 \%$, resp. During the first $0,25 \mathrm{l} / \mathrm{m}^{2}$ of runoff, the concentrations of $\mathrm{Pb}$ adsorbed onto suspended sediments differ greatly. We explain this by different amounts of dry deposition before onset of rain and different washoff efficiency of suspended sediments caused by roof roughness and resistance to flow rather than $\mathrm{pH}$-variation which was $\triangle \mathrm{pH}<0,5$ during the event.

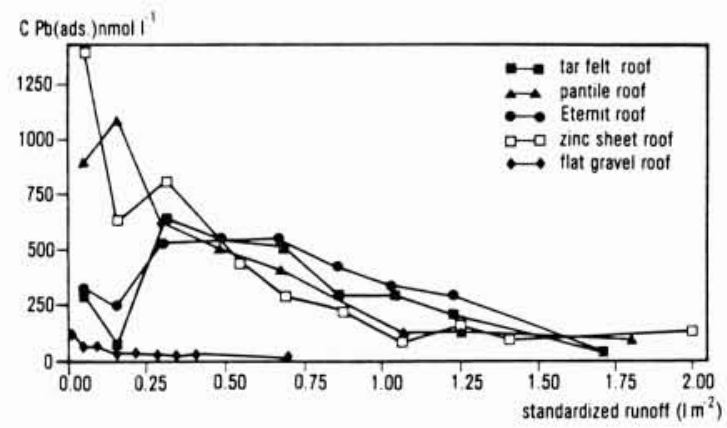

Figure 10: Concentrations of adsorbed $\mathrm{Pb}$ in roof runoff $(18 / 05 / 1988)$. 


\subsection{CHEMODYNAMICS OF Cu AND Pb DURING A RUNOFF EVENT}

Figs. 11 to 13 depict the temporal variations of various $\mathrm{Cu}$ and $\mathrm{Pb}$ fractions. We observe a well marked coherence between the temporal variation of coarse suspended sediments and the concentration of $\mathrm{Cu}$ adsorbed onto coarse suspended sediments, but with a temporal reversal of the height of the two peaks. It is evident that during peak washoff of coarse suspended sediments, these were only weakly contaminated. Even more clearly, this can be shown by means of the temporal variation of the specific adsorption of $\mathrm{Pb}$ and $\mathrm{Cu}$ onto coarse suspended sediments (s. fig. 13) where after $3 \mathrm{~h}$ at the time of peak washoff we observe a minimum of concentration. In general, the specific concentrations of $\mathrm{Cu}$ decreased : particles with higher contamination are preferably washed off. Further, at the time of the second peak of washoff of coarse sediments, we do not observe a change in specific concentration. Thus, at this time a higher washoff of particles leads to a proportional increase in particle bound copper. The washoff of $\mathrm{Cu}$ adsorbed onto fine suspended sediments follows the washoff of fine suspended sediments, with, however a distinctly higher specific concentration at the beginning. The concentration of dissolved $\mathrm{Cu}$ decreases with time in the same way as $\mathrm{Cl}$ - and electric conductivity which are indicators of conservative dissolved substances.
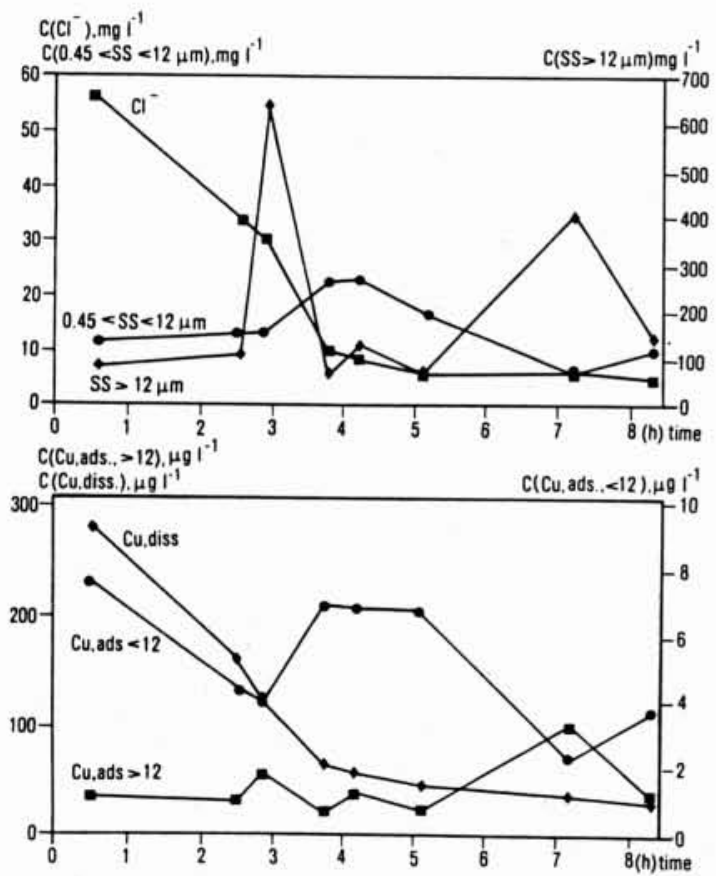

Figure 11: Temporal variation of concentrations $\mathrm{Cl}$, suspended sediments (SS $>12 \mu \mathrm{m}, 0.45<\mathrm{SS}<12 \mu \mathrm{m}$ ), top., Cu adsorbed onto particles ( $>12 \mu \mathrm{m}$ and $<12 \mu \mathrm{m}$ ) and dissolved Cu (Bayreuth, Königsallee 14/07/1991).

The temporal variation of $\mathrm{Pb}$ adsorbed onto coarse suspended sediments resembles that of $\mathrm{Cu}$. However, we do not observe a general decrease of specific concentrations such as with $\mathrm{Cu}$. Dissolved $\mathrm{Pb}$ and $\mathrm{Pb}$ adsorbed onto fine particles show a temporal variation similar to that of $\mathrm{Cl}$ - or electric conductivity and fine suspended sediments, resp. Thus, these temporal variations are similar to the resp. ones of $\mathrm{Cu}$.

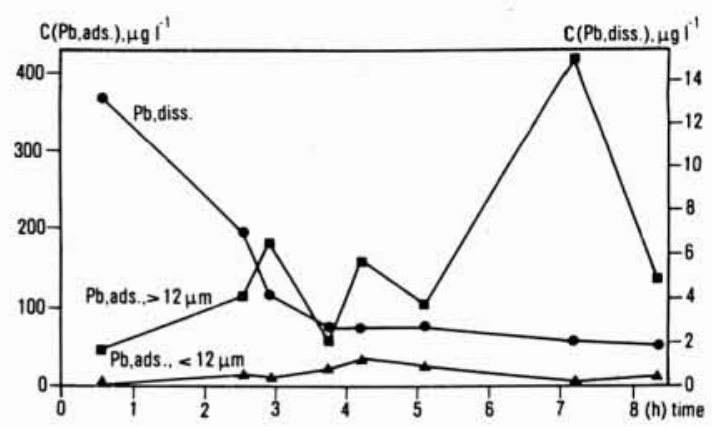

Figure 12: Temporal variation of concentrations of $\mathrm{Pb}$ (adsorbed onto particles $>12 \mu \mathrm{m},<12 \mu \mathrm{m}$ and dissolved) (Bayreuth, Königsallee 14/07/1991).

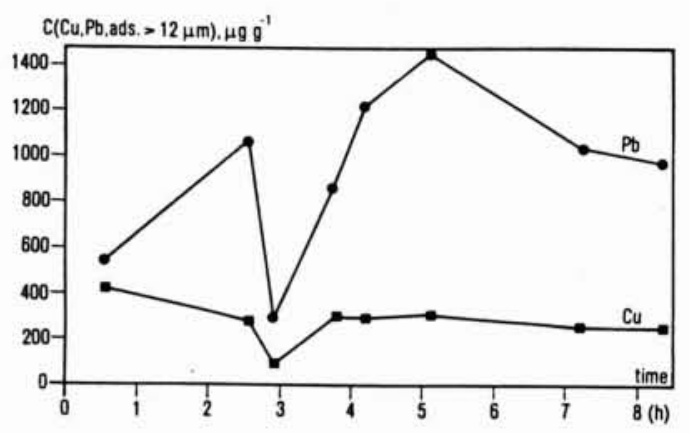

Figure 13: Temporal variation of concentration of $\mathrm{Pb}$ and $\mathrm{Cu}$ on suspended sediments $>12 \mu \mathrm{m}$ (Bayreuth, Königsallee 14/07/1991).

The specific concentrations of trace metals (mass trace metal/mass of sediment) adsorbed onto fine particles are greater than for coarse particles. However, in respect to the far greater surface area this difference in concentration is surprisingly low.

\section{ACKNOWLEDGEMENT}

We thank the German Research Council and the Federal Ministry of Research and Technology for support of this work. The discussion about the chemodynamics and transport behaviour of trace organics will be presented at the 6th I.C.U.S.D. in september 1993, Niagara Falls.

\section{REFERENCES}

CHIOU C.T., SHOUP T.D., PORTER P.E., 1985 - Mechanistic roles of soil humus and minerals in the sorption of nonionic organic compounds from aqueous and organic solutions. Org. Geochem., n 8, pp. 9-14.

FORSTER J., 1990 - Roof runoff : a source of pollutants in urban storm drainage systems. Proc. 5th Int. Conf. Urban Storm Drainage, Osaka, pp. 469-474.

FORSTER J., 1991 - Roof runoff pollution. In : Grottker M., Schilling W. (Eds.) - Hydrological and pollutional aspects of stormwater infiltration. Proc. Sec. Europ. Junior Scient. Workshop, Kastanienbaum, pp. 145-158.

HERRMANN R., DAUB J., STRIEBEL Th., 1992 - Qualitative Beurteilung der Niederschlagsabflüsse. In : $\mathrm{Hahn} \mathrm{H}$. H., Xanthopoulos C. - Schadstoffe im Regenabfluß II, Institut für Siedlungswasserwirtschaft, Karlsruhe, $n^{\circ} 64$, pp. 115-155.

KERN U., WUST W., DAUB J., STRIEBEL Th., HERRMANN R., 
1992 - Abspülverhalten von Schwermetallen und organischen Mikroschadstoffen im Straßenabflu $\beta$. gwf - Wasser/Abwasser, $n^{\circ} 133$, pp. 567-574.

LISS P.S., SLATER P.G., 1974 - Flux of gases across the air-sea interface. Nature, $n^{\circ} 247$, pp. 181-184.

RAO P.S.C., LEE L.S., NKEDI-KIZZA P., YALKOWSKY S.H., 1989 - Sorption and transport of organic pollutants at waste disposal sites.

In : GERSTL Z., CHEN Y., MINGELGRIN U., YARON B. Toxic organic chemicals in porous media - Springer, Heidelberg, pp. 176-192.

SALOMONS W., FORSTNER U., 1984 - Metals in the hydrocycle. Springer, Heidelberg.

SAWHNEY B.L., 1989 - Movement of organic chemicals through landfill and hazardous waste disposal sites. In : Sawhney B.L., Brown K. (Eds.) - Reactions and movements of organic chemicals in soils, Madison : Soil Sc. Soc. Am., pp. 447474.

STRIEBEL Th., DAUB J., HERRMANN R., 1993 - A sampling device for measuring physical and chemical characteristics of urban street runoff. The 4th International Symposium * Highway Pollution ", Madrid (in print).

ZAFIRIOU O.C., JOUSSOT-DUBIEN J., ZEPP R.G., ZIKA R.G., 1984 - Photochemistry of natural waters. Environ. Sci. Technol., $n^{\circ} 18$, pp. 358A-371A.

\section{DISCUSSION}

M BACHOC (DIREN-Centre, Service de Bassin Loire-Bretagne)

$M$ BRIAT, pouvez-vous nous dire quelles sont les caractéristiques des événements 4,5 et 6 que vous avez présentés et qui sont intéressants, non-seulement du point de vue de la grande proportion de pollution soluble pour un certain nombre de polluants métalliques, mais aussi parce que leur concentration en MES est de l'ordre de $25 \mathrm{mg}$ par litre, ce qui est assez surprenant et rare?

\section{BRIAT}

Les événements 5 et 6 avaient respectivement 22 et $26 \mathrm{mg} / \mathrm{lde}$ concentration moyenne en MES, ce qui est tout à fait exceptionnel. Cela nous a surpris.

Les caractéristiques des précipitations sont les suivantes: $14 \mathrm{~mm}$ pour l'événement 5 et $11 \mathrm{~mm}$ pour l'événement 6 . Ce sont des pluies que nous pouvons considérer comme moyennes.

\section{DESBORDES}

En ce qui concerne les échantillons, je constate que l'on continue à échantillonner à pas de temps constant. C'est peut-être plus simple pour faire fonctionner les appareils, mais sur le plan de la représentativité des mesures, ce n'est pas nécessairement justifié. Alors, pourquoi ne développe-t-on pas des techniques de prèlèvement qui sont asservies aux mesures des volumes passés et faisant des prélèvements en fonction du volume par exemple?

\section{BRIAT}

II nous a déjà fallu élaborer la courbe hauteur-débit et on ne connaissait les débits que par une courbe hauteur-débit qui n'était pas étalonnée au moment de l'installation. Ensuite, on a mesuré ces débits par cette courbe hauteur-débit et on a pu quand même recalculer les concentrations moyennes. On pensait qu'un temps de 10 minutes était quand même satisfaisant. On avait peut-être peur d'avoir des échantillons soit trop rapprochés, soit trop éloignés dans le temps les uns des autres si les débits variaient trop, mais on a pensé qu'avec un prélèvement d'échantillons toutes les 10 minutes on pouvait avoir, vu les vitesses de variation des paramètres, un échantillonage satisfaisant, du moins pendant la première heure et demie.

\section{DESBORDES}

En ce qui concerne la mesure des hydrocarbures, $M$ DUCREUX, vous avez donné des informations sur des recherches effectuées sur les précipitations. Le pluviomètre que vous avez utilisé était-il un pluviomètre fermé par temps sec ou ouvert?

\section{DUCREUX}

Nous avons utilisé deux types de pluviomètres : des pluviomètres qui étaient en permanence ouverts et d'autres qui n'étaient découverts qu'au moment des temps de pluie. On peut observer, mais cela n'apparait pas très nettement, que les concentrations en hydrocarbures obtenues sont un peu plus fortes sur le pluviomètre en permanence découvert. En ce qui concerne la nature des hydrocarbures, on a pu mettre en évidence des résultats quasiment identiques, excepté toutefois l'apparition de normale paraffine à répartition impaire en fin de chromatogramme, qui est caractéristique des cires cuticulaires que l'on rencontre chez les végétaux.

\section{$M$ GIERSCH}

Dans le cas des rinçages de toitures, est-ce que les différentes études ont pu permettre d'obtenir des conclusions ou des orientations de traitement, lorsque l'on veut par exemple respectivement infiltrer ou stocker sur la parcelle, pour réutiliser l'eau de toiture pour des questions d'arrosage, etc.?

\section{HERRMANN}

This, in fact is a great problem and a great discussion in Germany at the moment. We, ourselves, proposed that you'll use soakaways where you can infiltrate roof and road runoff, but one should give the first one or two minutes into the sewage plant, and only have the lower concentration at the end going into soakaways. 